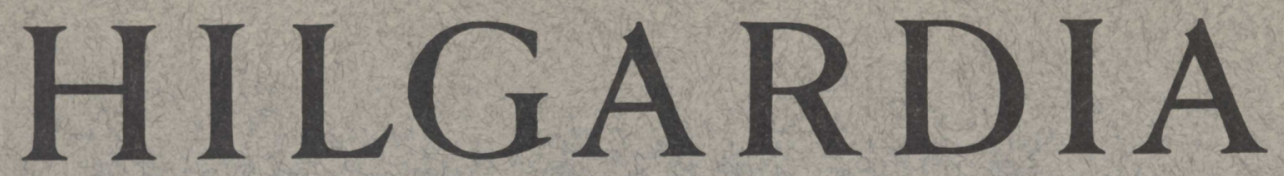

A Journal of Agricultural Science Published by the California Agricultural Experiment Station

\title{
THE EFFECTS OF PHOSPHORUS DEFICIENCY ON CITRUS
}

H. D. CHAPMAN and S. M. BROWN

\section{THE EFFECTS OF SULFUR DEFICIENCY ON CITRUS}

\author{
H. D. CHAPMAN and S. M. BROWN
}

\section{SPECIES OF STIGMINA AND STIGMELLA OCCURRING ON PLATANUS} DONALD J. SMITH and CLAYTON O. SMITH 
SPECIES OF STIGMINA AND STIGMELLA OCCURRING ON PLATANUS

DONALD J. SMITH AND CLAYTON O. SMITH 



\title{
SPECIES OF STIGMINA AND STIGMELLA OCCURRING ON PLATANUS ${ }^{1,2,3}$
}

\author{
DONALD J. SMITH“ AND CLAYTON O. SMITH ${ }^{5}$
}

\section{INTRODUCTION}

THE Four or FIVe species of Platanus, or plane trees, commonly known as "sycamores" in the United States, occur widely throughout North America, Europe, and Asia. These trees are notable for their picturesque beauty in their natural habitats and are widely planted for use as ornamentals on lawns and along streets. Their foliage, however, is subject to attack by various fungi, among which are species of Stigmina and Stigmella. These closely related conidial fungi possess oval to oblong brown spores, whose distinguishing characteristics are the transverse septa in those of Stigmina sp. and the muriform septa in those of Stigmella sp. These fungi have been reported to cause the production of lesions on the leaves of $P$. orientalis L., $P$. occidentalis L., and $P$. racemosa Nutt. The diseases which they cause are not of major importance, for they do not seriously threaten the destruction of the trees. In certain localities, however, and in certain seasons, the leaf spots are conspicuously abundant, and affected trees are prematurely defoliated.

Most plant pathologists and mycologists who have collected specimens of Stigmina and Stigmella on Platanus orientalis, P. occidentalis, and $P$. racemosa have regarded the pathogens as one and the same species, that is, Stigmina Platani (Fckl.) Sace. But, when this study was begun in December, 1935, at the University of California Citrus Experiment Station, it soon became apparent that the identity and nomenclature of these fungi were in a confused state. For this reason, a comparative study of Stigmina and Stigmella on Platanus was undertaken.

\section{ORGANISMS INVOLVED}

Three related but distinct fungi have been shown to be involved in these diseases: Stigmella Platani-racemosae Dearn. and Barth. apud Dearn. on Platanus racemosa, in California; Stigmina Platani (Fckl.)

\footnotetext{
${ }^{1}$ Received for publication October 28, 1940.

${ }^{2}$ Paper no. 438, University of California Citrus Experiment Station, Riverside, California.

${ }^{3}$ The major part of this paper is based on a thesis by the senior author submitted in partial fulfillment of the requirements for the degree of Master of Science, University of California, 1937. (Typewritten.) Copy on file in the Library of the University of California, Berkeley. The present paper includes further research undertaken, after the thesis was completed, in coöperation with the junior author.

4 Graduate student at the Citrus Experiment Station, 1935 to 1937.

${ }^{5}$ Associate in the Experiment Station; retired July 1, 1941.
} 
Sacc. on $P$. orientalis, in Europe; and a species of Mycosphaerella on $P$. occidentalis, in the southeastern and southern central United States. The third fungus was described as a new species by Wolf $(24)^{6}$ and named Mycosphaerella Stigmina-Platani, in the belief that it was the perithecial stage of Stigmina Platani. This Mycosphaerella has an unnamed polymorphic conidial stage, some of whose conidia are typical of the genus Stigmina, others of Cercospora, and still others intermediate in shape between these two types. Polymorphism in the conidial stage is indicated by Wolf (24, fig. 8). The conidial stage of Stigmina Platani does not show polymorphism. The evidence from pathogenicity, appearance of the disease, physiological characteristics, and morphology of the conidial stage, discussed later in the paper, indicates that the conidia of the Mycosphaerella on Platanus occidentalis are distinct from those of Stigmina Platani and that the Mycosphaerella described by Wolf (24) is apparently not the perithecial stage of Stigmina Platani.

It seems advisable, therefore, to reject the name Mycosphaerella Stigmina-Platani Wolf as untenable, according to the International Rules of Botanical Nomenclature (9), which states:

Art. 64. A name of a taxonomic group must be rejected if the characters of that group were derived from two or more entirely discordant elements, especially if those elements were erroneously supposed to form part of the same individual.

In its place, the name Mycosphaerella polymorpha is proposed, with the following description :

Mycosphaerella polymorpha $\mathrm{n} . \mathrm{n}$.

Mycosphaerella Stigmina-Platani Wolf (24, p. 60-61) nomum confusum.

Perithecia in vernale in putrescentibus foliis efformantia, hypophylla per totum folium dense dispersa, punctiformia, nigra, erumpenti-immersa, sphaeroidea, 65-85 $\mu$ diam.; ascis sacciformibus, fasciculatis, octosporis, aparaphysatis, 55-70 $\times 9-11 \mu$; sporidiis biseriatis, loculis inaequalibus, loculo superiore crassiore, hyalinis, rectis vel curvulis, 8-19 $84-7 \mu$.

Spermogoniis autumno efformantibus, numerosis, hypophyllis, innatoprominulis, paginis inferioribus ex toto vel in maculis exaridis occupantibus, ovatis vel globosis, nigris, 55-65 $\mu$; spermatiis bacilliformibus, $2-3 \times 1 \mu$, hyalinis.

Hab. in foliis dejectis Platani occidentalis.

Status conidicus: Statum conidicum Stigmina polymorpha n. n. sistit. Caespitulis hypophyllis, atris, primo maculicolis deinde subeffusis; conidiis polymorphicis, stigminoideis vel cercosporoideis, 14-70 $\times 3-11 \mu$, intense olivaceis, 1-8-septatis, nonconstrictis; conidiophoris fasciculatis, fuscidulis. Hab. stato conidico non modo in pagina inferiore Platani occidentalis parasitico sed in foliis vivis Platani racemosae, $P$. Wrightii, atque $P$. acerifoliae, in Amer. bor.

There remains, as will be indicated in this report, the possibility that the pathogen Mycosphaerella polymorpha on Platanus occidentalis has

\footnotetext{
"Italic numbers in parentheses refer to "Literature Cited" at the end of this paper.
} 
been confused with $M$. platanifolia (Cke.) Wolf. $M$. platanifolia was first described from leaves of $P$. occidentalis by Cooke (3) as Sphaerella platanifolia, and its conidial stage is stated by Wolf (24 and 25) to be Cercospora platanicola Ellis and Everhart (5).

Whether the organism identified by Saccardo (20) as Stigmina Visianica Sacc. is correctly named, has been questioned by Bubák (2, p. 219), who says :

Bei einem amerikanischen Exemplare dieses Pilzes (Claremont bei Los Angelos in Süd-Kalifornien, Platanus racemosa, leg. Baker) finde ich sehr oft auch Sporen mit einer Längswand, so dass die Unterschiede zwischen Stigmella und Stigmina nicht allzu fest sind.

Die zweite europäische Art Stigmina Visianica Sacc. ist von St. Platani nicht verschieden. Schon Lindau .... weist auf diesen Umstand hin. Ich finde die Sporen bei beiden genannten Arten sehr variabel und gleich gross. Demnach ist Stigmina Visianica Sacc. nur ein Synonym zu Stigmina Platani (Fuckel) Saccardo.

A specimen from the Farlow Herbarium, bearing the notation "Stigmella Visianica Sacc.? if it is different from Stigmina Platani f. Ellis. Pine Hills, Illinois, September 1884," was examined by the writers and found to be similar to the fungus on Platanus occidentalis, herein identified as Mycosphaerella polymorpha.

\section{HISTORY AND DISTRIBUTION OF THE FUNGI}

The name Stigmina Platani was employed by Saccardo in 1878 (18) and in 1880 (19) for an organism called, as early as 1815, Puccinia Platani Bivona. Later, Saccardo (20) used the name Stigmina Platani also to replace that of Stigmella Platani Fuckel, employed by Thümen (22) for the same organism. Specimens of this fungus had been sent from Greece to Thümen and transmitted by him to Fuckel, who, in 1873, named the fungus Stigmella Platani. That it occurs elsewhere in Europe is evidenced by the fact that Saccardo (20) records it from Germany, Bubák (2) from Tirol (Austria) and Istria (Italy), and Nattrass (13) from Cyprus.

The fungus now known as Stigmella Platani-racemosae was stated by Harkness (7), who collected it on Platanus racemosa near Niles, in Alameda County, California, to have been present in California as long ago as 1885; and its presence in this state was mentioned by McClatchie $(12$, p. 376) in 1897. Both Harkness and McClatchie called it Stigmina Platani, however, in the belief that it was identical with the organism occurring in Europe on P. orientalis. Apostolides (1), in 1929, studied this disease in California and also identified the causal fungus as Stigmina Platani. In the same year, Dearness and Bartholomew (Dearness, 4) described this pathogen as Stigmella Platani-racemosae, recognizing 
that the leaf-spot fungus on $P$. racemosa was distinct from Stigmina Platani and basing their description upon specimens collected at Riverside, California. Specimens in the Claremont College herbarium (Baker's collection no. 3956), identified as Stigmina Platani on P. occidentalis, were examined by the writers and found, also, to be Stigmella Plataniracemosae on $P$. racemosa.

To date, Stigmella Platani-racemosae is not known to occur outside of California. Through correspondence with interested collectors, the writers have determined that the fungus is present in the following counties in southern California : San Diego, Los Angeles, Orange, Riverside, San Bernardino, Santa Barbara, and Ventura. It has not been collected in the northern part of the state except by Harkness (7).

The fungus Mycosphaerella polymorpha is of widespread occurrence on Platanus occidentalis in the southeastern and southern central United States, especially in the valleys of the lower Ohio and lower Mississippi rivers. Among the early records of the occurrence of this fungus (under different names) is that of Jennings (10) in 1890, in Texas; Tracy and Earle (23, p. 116) in 1895, in Mississippi; Patterson (14, p. 31) in 1902, in Illinois. Later, Hoffer (8) and Pipal (15) recorded its occurrence in Indiana. And in 1925, Martin (11, p. 380) reported that the conidial stage of this organism on P. occidentalis had been collected in Arkansas, Georgia, Illinois, Indiana, Iowa, Louisiana, Mississippi, Missouri, North Carolina, Oklahoma, Texas, and West Virginia.

The writers have examined specimens of Mycosphaerella polymorpha from Arkansas, Illinois, Mississippi, Missouri, North Carolina, and Oklahoma, and have found them all to be specifically identical and distinct from Stigmina Platani from the Old World and also from Stigmella Platani-racemosae from California.

\section{MATERIALS USED}

The materials used in these studies were from many different sources. Herbarium specimens of leaves were generously loaned by Claremont College, Claremont, California, and by Dr. D. S. Welch, of Cornell University. Herbarium specimens and information were provided by the Farlow Library and Herbarium, Harvard University; by the University of California Herbarium, Berkeley; and by the University of California Citrus Experiment Station, Riverside. Freshly pressed leaves of Platanus occidentalis affected by Mycosphaerella polymorpha were received from Dr. Frederick A. Wolf of Duke University; and leaves of $P$. orientalis affected by Stigmina Platani were received from Dr. R. M. Nattrass, Mycologist, Nicosia, Cyprus. Leaves of P. racemosa affected by Stigmella Platani-racemosae were collected by the writers in California. 
The species of Platanus used in the inoculation experiments were: (1) P. orientalis, trees grown from seed sent by Professor P. Th. Anagnostopoulos, Superior School of Agriculture, $\Lambda$ thens, Greece; (2) $P$. Wrightii S. Wats., trees grown from seed and cuttings from Dr. R. B. Streets, University of Arizona; (3) P. occidentalis, trees grown from cuttings from Dr. Carroll W. Dodge of the Missouri Botanical Garden, and trees from local nurseries; (4) P. acerifolia Wild (hybrid), trees from local nurseries; and (5) P. racemosa, trees from local nurseries and trees growing on the Citrus Experiment Station campus.

\section{APPEARANCE OF THE DISEASES}

Both macroscopic and microscopic differences may be employed in distinguishing these diseases.

Macroscopic Appearance.-Leaf-spot disease on Platanus racemosa, caused by Stigmella Platani-racemosae (fig. $1, A-C$ ), is manifested by the presence of small, effuse, black-colored areas, 1 to $3 \mathrm{~mm}$ in diameter, on the lower surfaces of the leaf blades and on the stipules. These areas generally increase in diameter to about $1 / 2 \mathrm{~cm}$, but the entire lower leaf surface may become blackened because of numerous secondary infections. The blackening is produced by the abundance of conidiopliores and conidia. If the lesions are widely scattered, the spots may gradually enlarge to $1 \mathrm{~cm}$ in diameter. The leaf tissues immediately above the fungus (fig. 1, $A$ ) are at first yellow, but later become brown and necrotic. The margins of the spots are usually definite, irregular, and surrounded by green tissue.

Lesions on Platanus orientalis caused by Stigmina Platani (fig. 1, $F$ ), as observed on herbarium material from Cyprus, are very similar in general appearance to the spots on $P$. racemosa caused by Stigmella Platani-racemosae. The two diseases can best be distinguished by comparative microscopic examination of the conidiophores and conidia (see "Microscopic Appearance," below.)

Lesions produced by the conidial stage of Mycosphaerella polymorpha are at first pale-green, indefinitely limited areas, if viewed from the upper leaf surface. Thin, weftlike gray stippled areas (fig. 1, D) cover the corresponding areas on the lower leaf surface. When the disease has progressed to the extent that a large proportion of the upper leaf surface is pale green, the entire lower leaf surface may be invested with an effuse gray coating (fig. 1, $E$ ) of conidia and conidiophores. At this stage, which may have developed by midsummer, the trees will appear blighted, and defoliation will have begun.

Microscopic Appearance.-Sections of lesions caused by Stigmella Platani-racemosae on Platanus racemosa show the fungus to be localized 
at first in the stomatal chambers (fig. 2, I). Later, hyphae are produced that ramify between the cells; these may extend throughout the tissues to the upper epidermis. Mycelia and haustoria were not found within the cells when sought in paraffin sections or in freezing microtome sec-

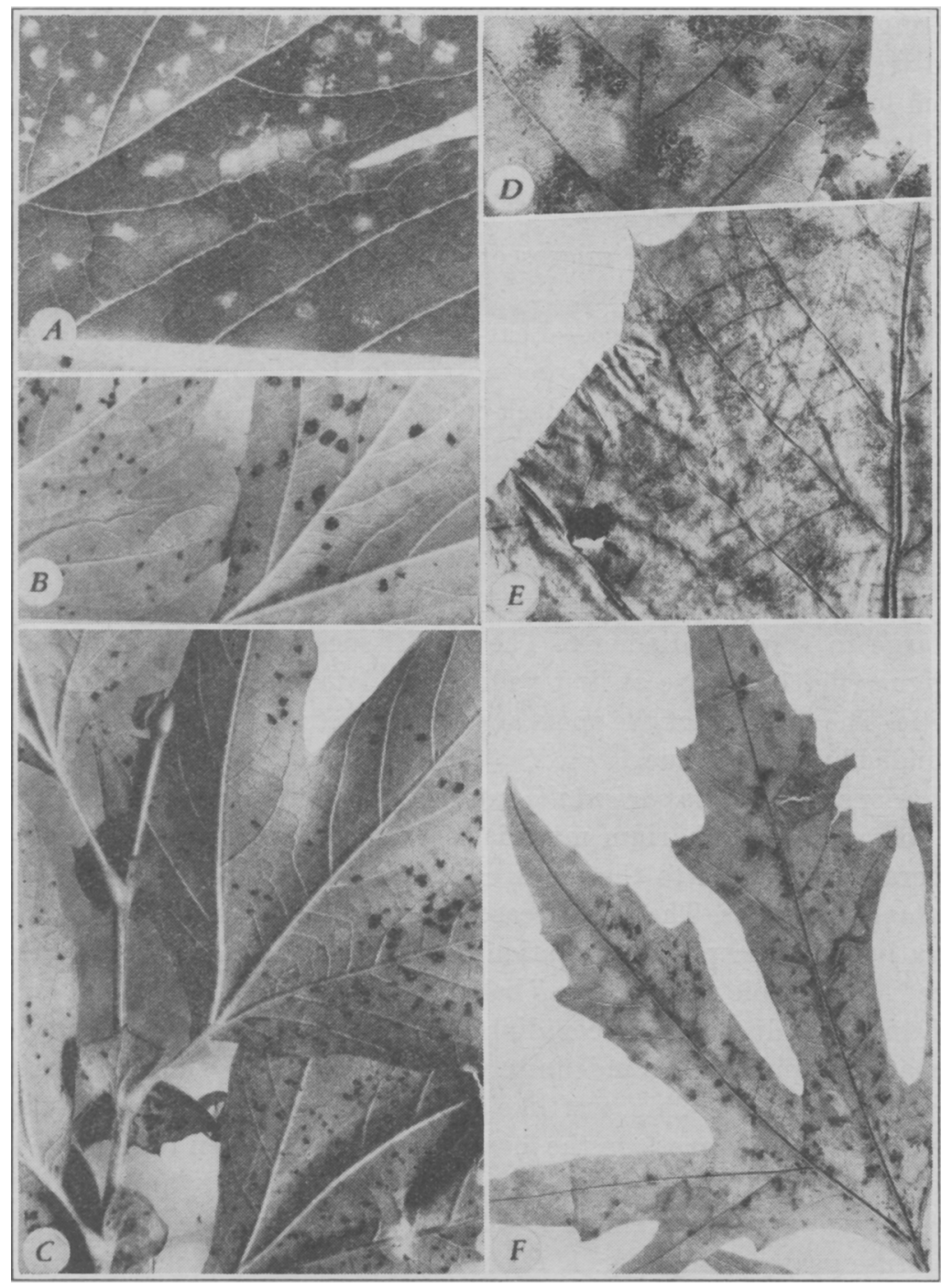

Fig. 1.-Natural infection on leaves of Platanus spp.: A-C, Stigmella Platani-racemosae on $P$. racemosa-A, showing as spots on upper leaf surface; $B$, on lower leaf surface; $C$, on lower leaf surface and on stipules. $D, E, M y c o$ sphaerella polymorpha on lower leaf surfaces of $P$. occidentalis. $F$, Stigmina Platani on lower leaf surface of $P$. orientalis (from Cyprus). 

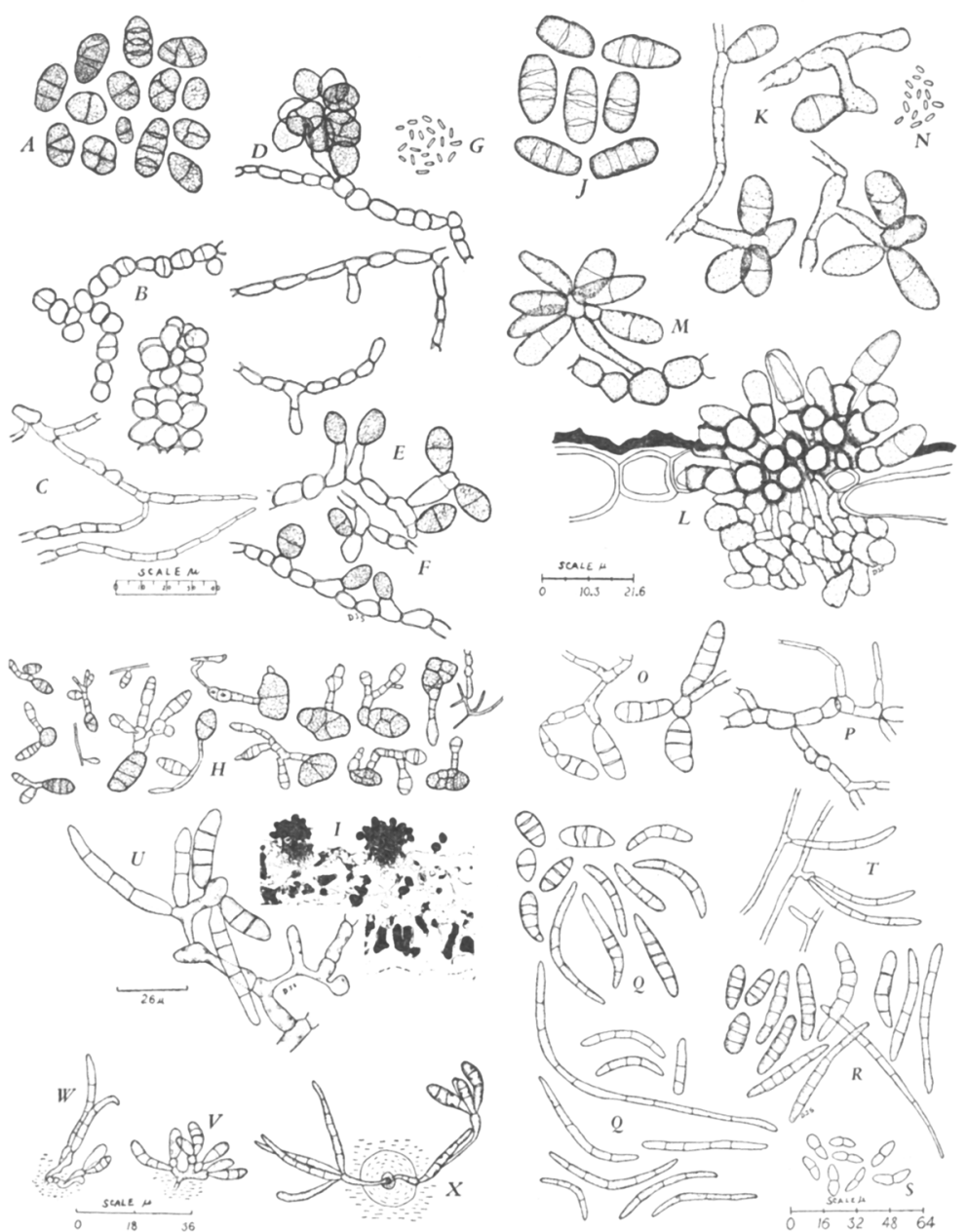

Fig. 2.-Camera-lucida drawings of spores and mycelium of species of Stigmina and Stigmella on Platanus spp.

Stigmella Platani-racemosae from Platanus racemosa, $A-I: A$, conidia; $B$, mycelium thick, dark and massed; $C$, mycelium hyaline and slender; $D$, attachment of spores to mycelium ; $E, F^{\prime}$, mycelium, conidia, and conidiophores, showing spore formation; $G$, spermatia from pure culture; II, spore germination in drops of water on slides (germinating spores gave rise to additional spores, but attempt at repetition of these results was unsuccessful); $I$, section showing conidia and conidiophores growing out of stomatal chambers $(\times 305)$.

Stigmina Platani from Platanus orientalis, $J-N: J$, spores from type species; $K$, spores and mycelium produced on Czapek's-agar film on slide; $L$, section of living material ; $M$, spores, showing attachment; $N$, spermatia from pure culture growing in leaf juice on filter paper.

Mycosphaerella polymorpha from Platanus occidentalis, $O-X: O$, Stigmina-type spores from culture from single-spore isolation of Cercospora type, growing in leaf juice on slide, after 21 days: $P$ mycelinm from same culture: $Q$, Cercospora- and $S$ tigmina-type spores from an infection on $P$. racemosa by an isolate from a single Cercospora spore, after 56 days; $R$, dark-colored, subhyaline spores of Stigmina and Cercospora types from culture from single-spore isolation of Stigmina type on Czapek's agar; $S$, ascospores from a dead leaf; $T$, Cercospora-type spores from Czapek's-agar film on slide, after 21 days; $U$, sporulation, on slide, of growth from a single Cercospora spore, showing variation in spores attached to a conidiophore; $V-X$, spores from artificial inoculation on leaf of $P$. acerifolia (the culture used in this inoculation was from a single Cercospora-type spore from a single-spore-culture inoculation that had fruited only Cercospora-type spores) $-V$, showing variation in spores attached to a conidiophore; $W$, different types of spores attached to single hypha; $X$, mycelial growth from base of a leaf hair and two types of spores. 
tions stained with the differential stains, safranin light-green, triple stain, or iron-alum - hemotoxylin, applied according to methods outlined by Rawlins (16). Conidia are produced singly on conidiophores from fascicles projecting through the stomata. Affected leaf tissue shows fewer chloroplasts than normal tissue.

A study of freehand sections of leaf spots caused by Stigmina Platani

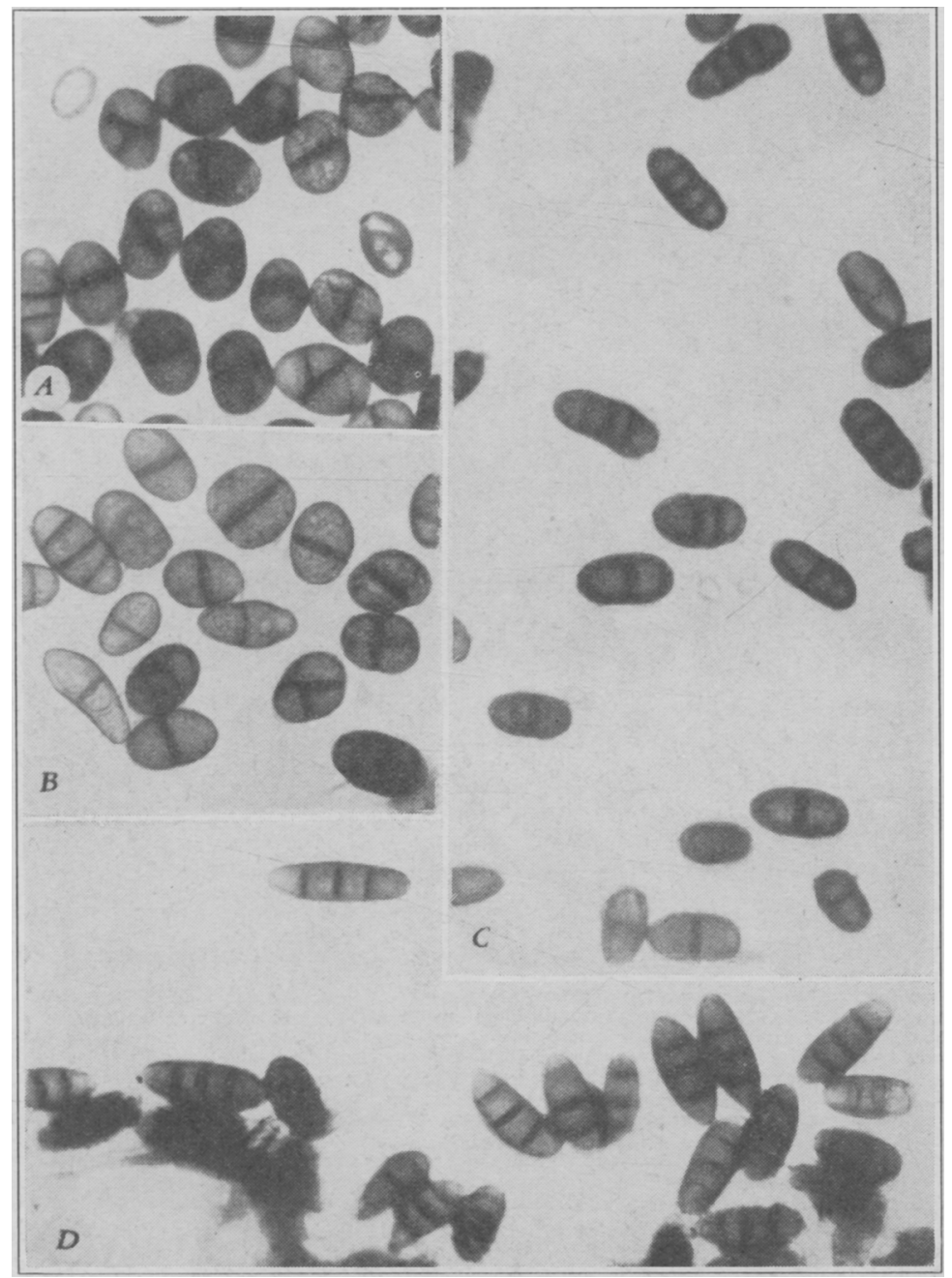

Fig. 3.-Photomicrographs of conidia of the three species of fungi: $A, B$, Stigmella Platani-racemosae from natural infection on Platanus racemosa, Riverside, California ; $C$, Stigmina Platani from $P$. orientalis from Nicosia, Cyprus ; D, Stigmina sp. (Mycosphaerella polymorpha) from Fungi Columbiana no. 2885 on $P$. occidentalis collected at Rogers, Arkansas. (All $\times 667$.) 
on Platanus orientalis (fig. 2, L) and by Mycosphaerella polymorpha on $P$. occidentalis indicated that the relations of the pathogens to the diseased tissues in these species are similar to those found in P. racemosa.

The conidia of the three fungi, while somewhat similar in appearance, are sufficiently distinct to suggest three different species. The Stigmina type of conidia are oblong, dark-colored, septate bodies (fig. 3, $C$ ). The Stigmella type differed in having numerous irregular septations (fig.

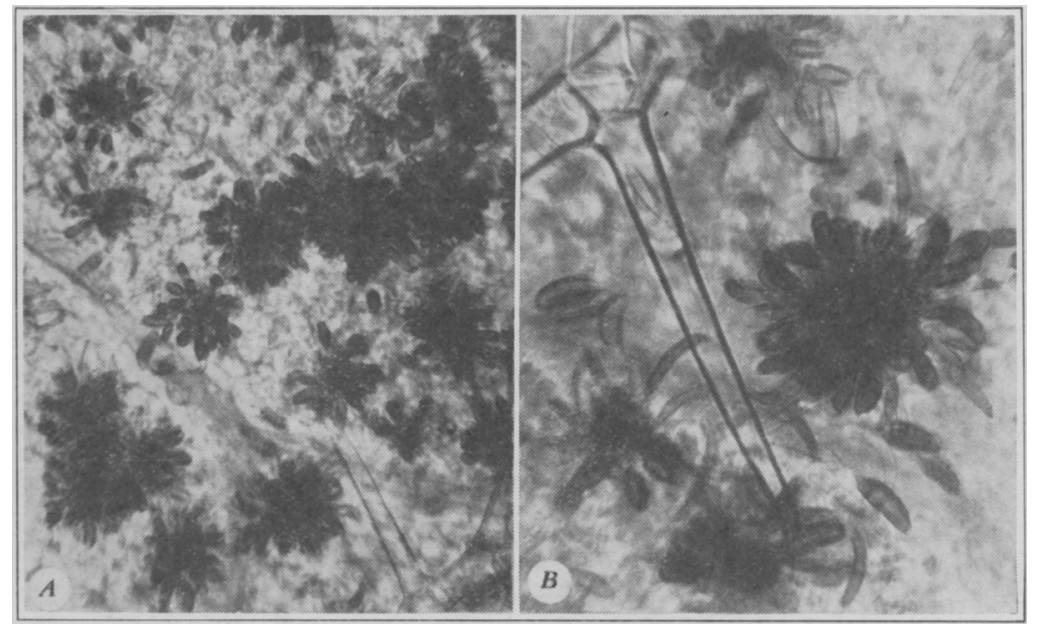

Fig. 4.-Fruiting of fungus on leaf of Platanus racemosa, from artificial inoculation with conidial spores of Mycosphaerella polymorpha taken from a diseased leaf of $P$. occidentalis from North Carolina: A, Stigmina- and Cercospora-type conidia shown in the same spore clusters $(\times 149) ; B$, fruiting of fungus $(\times 305)$.

$3, A, B)$. The conidia of Mycosphaerella polymorpha were variable in size and shape, as illustrated in figure 4 and in figure $2, Q, R, T$, but often the Stigmina type (fig. $3, D$ ) were the only ones to be found.

\section{MORPHOLOGICAL COMPARISON OF THE THREE FUNGI}

Conidial spores of the three fungi, Stigmella Platani-racemosae, Stigmina Platani, and Mycosphaerella polymorpha, taken directly from their respective primary hosts, show wide variation in size and septation (table 1 and fig. 2). While individual spores cannot always be identified with certainty as belonging to one or the other of these three species, conidia of each species, en masse, in spite of variations in septation and size, are sufficiently distinctive to make identification possible.

Conidia of Stigmella Platani-racemosae (figs. 2, $A$, and 3, $A, B$ ) are ovate to oblong, $10-22 \times 7-13 \mu$. Septations range from one to three cross 


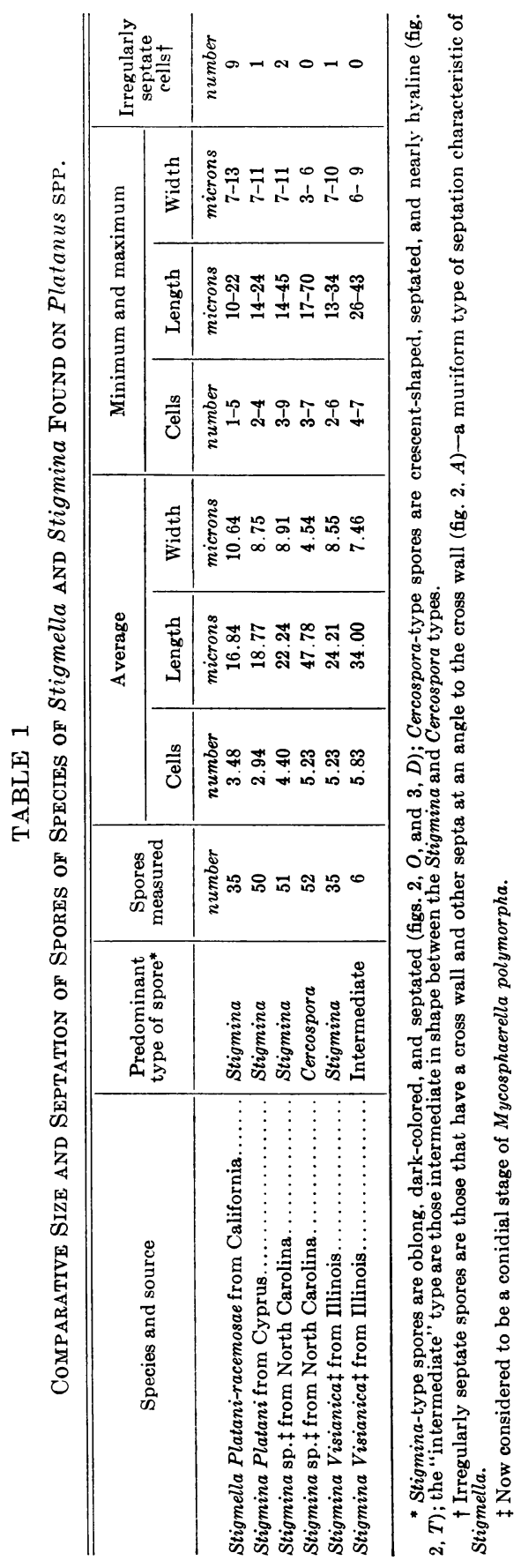


septa or from one to four diagonal or irregular septations. The abundant, irregularly septate spores distinguish this fungus from the fungi on Platanus orientalis (figs. 2, $J$, and $3, C$ ) and on P. occidentalis (figs. 2, $O-T$, and $3, D)$.

Conidia of Stigmina Platani from Platanus orientalis are narrower, and some are longer than those of Stigmella Platani-racemosae, as indicated by the dimensions, 14-24 $\times 7-11 \mu$, given in table 1 . These spores rarely show the irregular septa characteristic of Stigmella.
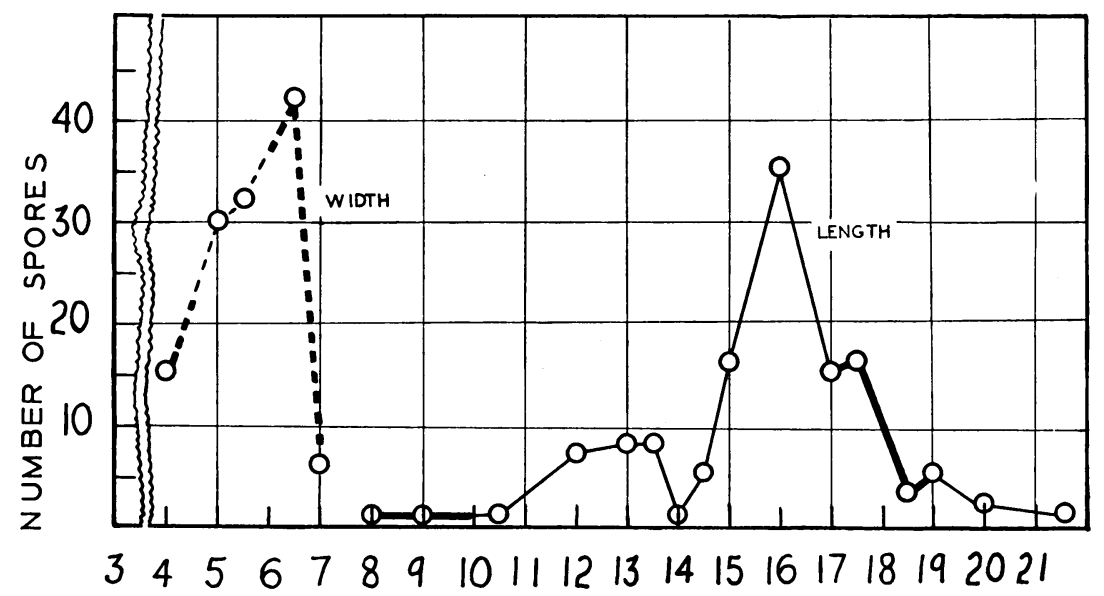

SIZE OF SPORES IN MICRONS

Fig. 5.-Frequency-distribution curves of measurements of 125 ascospores of Mycosphaerella polymorpha. Heavy lines indicate measurements corresponding with those of Wolf's (24) deseription of what he called M. platanifolia and M. StigminaPlatani.

The Stigmina-type spores of Mycosphaerella polymorpha (figs. 2, O, and $3, D)$ are more elongate and have more acute ends than those of the two other species. They are oval, dark, thick-walled, and have been found to measure 14-45 $\times 7-11 \mu$ (table 1 ). Cercospora-type spores are still more elongate, are light brown to dark brown in color, thinner-walled, and usually curved or crescent-shaped (fig. $2, T$ ); they measure around 17-70 $\times 3-6 \mu$, although spores $120 \mu$ in length have been found. Between these two types there are other spores intermediate in shape and size.

One hundred and twenty-five ascospores of Mycosphaerella, ejected from leaves into drops of distilled water suspended on the inside cover of a petri dish, were measured under an oil immersion; they ranged in size from 8-19 $\times 4-7 \mu$. (Ascospores from the same leaves were ejected onto agar media for culture studies ; see p. 219.)

A frequency-distribution curve (fig. 5) shows a number of spores of an intermediate size that apparently bridges the gap between the spore 
sizes of Mycosphaerella polymorpha and $M$. platanifolia (Cke.) Wolf (24). Wolf ${ }^{7}$ states, however, that two population curves are shown here (fig. 5), and that measurements of a larger number of spores should confirm this.

\section{PATHOGENICITY}

Inoculations of Platanus spp. with fungi of Stigmella and Stigmina spp. were made by the following procedures. (1) Conidia from the leaves or from pure cultures of the fungi were suspended in water. The fungus suspension was applied to the leaves and young shoots by means of either a camel's-hair brush or an atomizer. In nearly all of these tests, a paraffin-paper or cellophane bag or a bell jar was used as a covering to maintain moisture conditions favorable for infection. This protection also prevented fortuitous dissemination and spread of the fungi used in the inoculations. The paper bags (fig. $6, C$ ) were not sealed but had their edges twice-folded and kept in place by means of paper clips. In preliminary experiments, it was found that injuries, such as perforations made with a pin, were not necessary for infection, for infections seldom occurred in the loci of injuries but were common between them. (2) Infected leaves were pinned to normal leaves, which were then covered with paraffin-paper or cellophane bags. This method was very satisfactory in moist weather. (3) Spores and bits of mycelium from singlespore cultures of each of the three organisms were placed on leaves enclosed in cellophane bags. Each of the three causal organisms was later recovered in pure culture from the artificially inoculated leaves. Results of the tests are given in table 2.

The fungus Stigmella Platani-racemosae caused infection and spread rapidly both on Platanus Wrightii (fig. $6, E$ and $F$ ) and on $P$. racemosa (fig. 6, G-I). So far as can be determined, this fungus has not previously been reported on $P$. Wrightii. It failed repeatedly, however, to produce infection when inoculated on $P$. orientalis, $P$. occidentalis, and $P$. acerifolia (hybrid trees).

Inoculations with Stigmina Platani (Cyprus strain) from Platanus orientalis resulted in infection on $P$. orientalis (fig. $6, A$ ), but were ineffective on $P$. racemosa, $P$. Wrightii, $P$. occidentalis, and $P$. acerifolia.

Ascospores and conidia of both Stigmina and Cercospora types of $M y$ cosphaerella polymorpha from Platanus occidentalis produced infection on $P$. occidentalis (fig. $6, D), P$.racemosa, $P$. Wrightii, and $P$. acerifolia, but no infections developed on $P$. orientalis. All inoculations with cultures from single conidia of the Stigmina type of Mycosphaerella polymorpha produced some spots on which the Cercospora-type conidia were

\footnotetext{
${ }^{7}$ Wolf, F. W. In letter to the senior author dated October 17, 1938.
} 


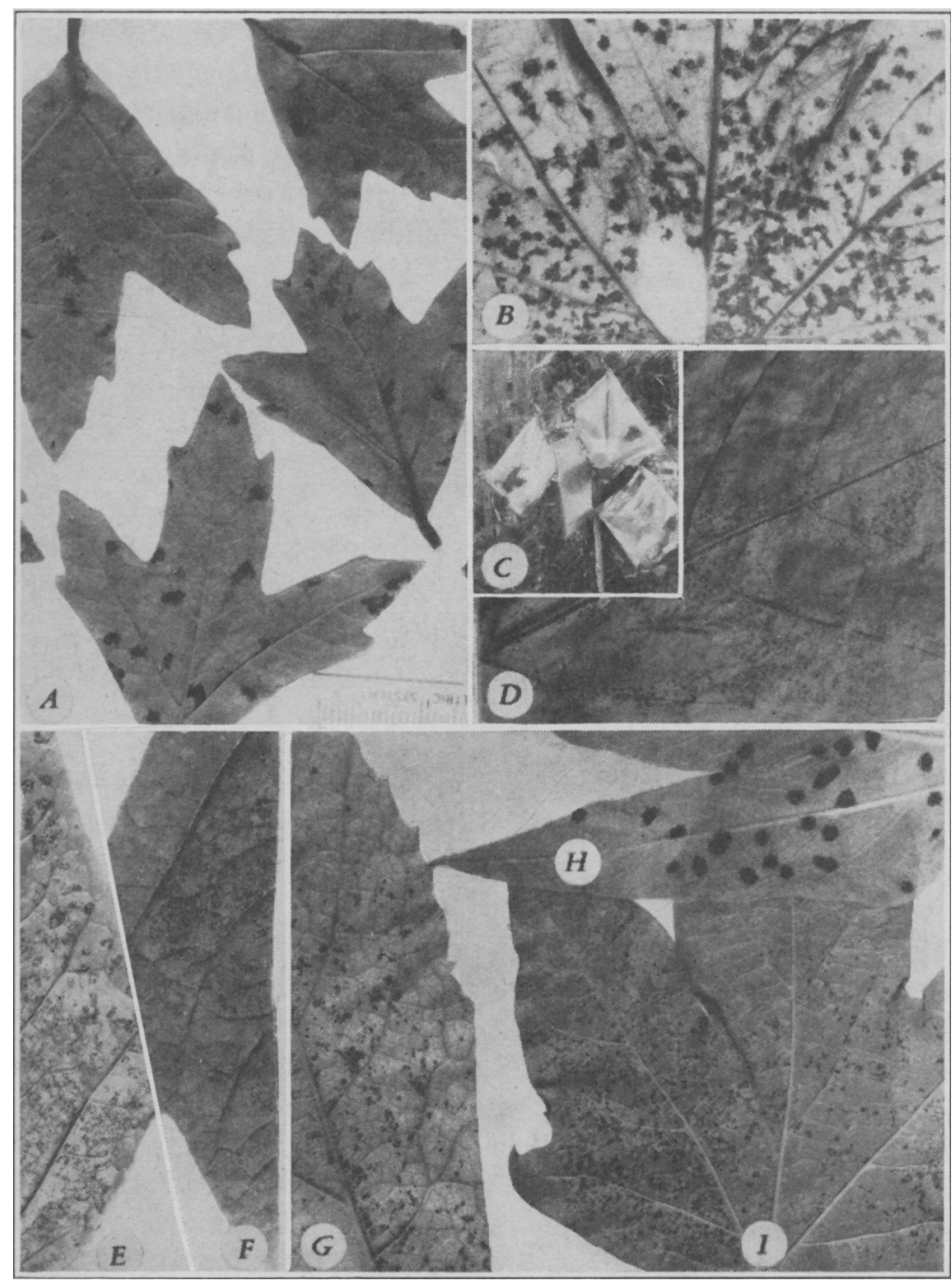

Fig. 6.-Artificial inoculations on species of Platanus : A, Stigmina Platani on young leaves of $P$. orientalis; $B, M y c o s p h a e r e l l a$ polymorpha (from natural infection) on $P$. racemosa; $C$, inoculated leaves protected by paraffin-paper bags; D, Mycosphaerella polymorpha (culture from a single Stigmina-type spore isolated from $P$. occidentalis from North Carolina) on authentic leaf of $P$. occidentalis, where Stigmina- and Cercospora-type spores fruited in abundance; $E-I$, Stigmella Platani-racemosae- $E$ and $F$, on upper and lower surfaces, respectively, of young leaf of $P$. Wrightii, after one month; $G$, on succulent leaf of $P$. racemosa, after one month; $H$, on normal leaf after three months; and $I$, after one month. 
found. Most inoculations with Cercospora-type conidia produced some spots in which the Stigmina-type conidia were found. Usually a mixture of the two forms of conidia, together with conidia intermediate in form, was found on lesions resulting from single-spore inoculations. In some cases the fascicles bore Stigmina-type conidia only ; in others, conidia of the Cercospora-type only; and in others, both types were formed on one and the same fascicle. Variations in conidia from single-spore cultures are shown in figure $2, U-X$ (p. 211).

\section{TABLE 2}

Results of INoculations of Platanus SPP. WITH Fungi of Stigmella AND Stigmina SPP.

\begin{tabular}{|c|c|c|c|c|c|c|}
\hline \multirow{3}{*}{ Host } & \multicolumn{6}{|c|}{ Single-spore inoculations } \\
\hline & \multicolumn{2}{|c|}{$\begin{array}{l}\text { Stigmella Platani- } \\
\text { racemosae from } \\
\text { Platanus racemosa }\end{array}$} & \multicolumn{2}{|c|}{$\begin{array}{c}\text { Stigmina } \text { sp.* }^{*} \\
\text { from } \\
\text { Platanus occidentalis }\end{array}$} & \multicolumn{2}{|c|}{$\begin{array}{l}\text { Stigmina Platani } \\
\text { from } \\
\text { Platanus orientalis }\end{array}$} \\
\hline & $\begin{array}{c}\text { Positive } \\
\text { results }\end{array}$ & $\begin{array}{l}\text { Negative } \\
\text { results }\end{array}$ & $\begin{array}{l}\text { Positive } \\
\text { results }\end{array}$ & $\begin{array}{c}\text { Negative } \\
\text { results }\end{array}$ & $\begin{array}{l}\text { Positive } \\
\text { results }\end{array}$ & $\begin{array}{c}\text { Negative } \\
\text { results }\end{array}$ \\
\hline Platanus acerifolia. & 0 & 5 & 8 & 0 & 0 & 8 \\
\hline P. occidentalis..... & 0 & 9 & 4 & 3 & 0 & 10 \\
\hline P. orientalis... & $\mathbf{0}$ & 7 & $\mathbf{0}$ & 5 & 3 & 1 \\
\hline P. racemosa.. & 10 & 0 & 10 & 5 & 0 & 8 \\
\hline P. Wrightii... & 7 & $\mathbf{0}$ & 5 & 3 & 0 & 4 \\
\hline
\end{tabular}

* Conidial stage of Mycosphaerella polymorpha.

The minimum time from inoculation to the beginning of sporulation was about three weeks. In the cooler spring months, the period of incubation was from four to five weeks.

When the surface of leaves atomized with conidia of Stigmella Plataniracemosae was stained with safranin, germ tubes entering the stomata could occasionally be found. When surface growth on very young spots was removed, the substomatal areas were observed to be darkened. The absence of darkening elsewhere indicated that the fungus growth was confined to the stomatal areas. Stained paraffin sections of very young spots also showed the fungus localized in the stomatal cavities, with no growth elsewhere (fig. 2, I, p. 211). Infection was often abundant on the lower surface of uninjured leaves of Platanus racemosa that had been atomized with a spore suspension. These microscopic observations indicate that the pathogen penetrates by way of the stomata. Similar results were obtained with Stigmina Platani and Mycosphaerella polymorpha; so that each fungus appears to have the same mode of entrance into the leaves and the same type of subsequent growth within the substomatal tissues. 
If susceptibility to infection is an index of relationship, artificial inoculations indicate that Platanus racemosa and $P$. Wrightii are closely related and that $P$. occidentalis is more closely related to the American species of Platanus than to the European, $P$. orientalis.

\section{CULTURE STUDIES}

Methods and Media.-The fungi were isolated in single-spore cultures by streaking suspensions of conidia on the surface of agar plates, where they could be observed in position under the high power of a binocular microscope ; then by proper manipulation, single conidia could be picked up with a sharp needle and transferred to media in test tubes. Cultures from ascospores were obtained on agar in petri dishes inverted over moistened dead leaves, from the surface of which the perithecia protruded and discharged the spores onto the surface of the agar.

The media used, in the order of decreasing suitability for sporulation, were as follows : (1) Platanus racemosa leaf juice sterilized by filtration, (2) a special medium described by Smith and Smith (21) and made by the aseptic addition of an equal amount of the leaf juice to 4 per cent Czapek's agar, (3) Czapek's agar, (4) leaf-extract agar containing 3 per cent sucrose, (5) glucose potato agar, and (6) carrot plugs.

Filtered leaf juice was used both on slides supported on U-shaped glass rods in petri dishes and in Van Tieghem cells, for comparison of the sporulation of isolates from different types of spores. Living leaves were used for certain tests.

Results.-By these procedures, single-spore cultures of Mycosphaerella polymorpha were isolated as follows : 147 from Cercospora-type conidia, 165 from Stigmina-type conidia, and 76 from ascospores. Results of the tests are presented in table 3 .

In other tests (not reported in table 3), 8 transfers from ascospore cultures of Mycosphaerella polymorpha onto Czapek's agar yielded 5 cultures that produced both Stigmina- and Cercospora-type spores, 1 culture that produced only Cercospora-type spores, and 2 that did not sporulate. Three isolates of Cercospora-type spores, when grown on Czapek's agar, yielded 2 cultures that produced only Stigmina-type spores and 1 that produced both Stigmina- and Cercospora-type spores.

Single-spore isolations of Mycosphaerella polymorpha, whether from conidia or from ascospores, produced on Czapek's agar two general types of colonies (fig. 7) about equal in number. One type was flat, light mouse gray to mouse gray (17); the other type was elevated and smaller in diameter than the first type under the same growing conditions. The color of the latter type was a similar gray, some colonies having white areas, however, and black margins (fig. 7). With age, a light-yellow 
color sometimes appeared. When viewed from beneath, both types of colonies appeared dark olive-gray to olivaceous black (17). Colonies produced on glucose potato agar were usually much elevated and gray to black in color. On a basis of minor differences, the colonies could be

\section{TABLE 3}

SPORULATION OF Mycosphaerella polymorpha FROM SINGLE-SPORE IsOLATIONS in Culture Media ANd on Leaves of Platanus racemosa

\begin{tabular}{|c|c|c|c|c|}
\hline \multirow[b]{2}{*}{$\begin{array}{l}\text { Type of spore isolated } \\
\text { and medium inoculated }\end{array}$} & \multirow[b]{2}{*}{$\begin{array}{c}\text { Total } \\
\text { inoculations }\end{array}$} & \multicolumn{3}{|c|}{$\begin{array}{l}\text { Infections from different types } \\
\text { of sporulation }\end{array}$} \\
\hline & & $\begin{array}{l}\text { Cercospora- } \\
\text { type }\end{array}$ & $\begin{array}{l}\text { Stigmina- } \\
\text { type }\end{array}$ & $\begin{array}{c}\text { Mixed, } \\
\text { Cercospora } \\
\text { and } \\
\text { Stigmina* }\end{array}$ \\
\hline Cercospora: & number & number & number & number \\
\hline Living leaves (March, 1938). & 1 & 1 & 0 & 0 \\
\hline Living leaves (April, 1938). & 1 & 1 & 0 & 0 \\
\hline Living leaves (May, 1938). & 4 & 0 & 1 & $3 \mathrm{C}$ \\
\hline Living leaves (June, 1938).. & 9 & 3 & 1 & $5 \mathrm{C}$ \\
\hline Living leaves (September, 1938)... & 12 & 0 & 1 & $5 \mathrm{C}$ and $6 \mathrm{~S}$ \\
\hline Czapek's agar............... & $16 \dagger t$ & 7 & 0 & $8 \mathrm{C}$ \\
\hline Leaf juice on slides............. & 3 & 2 & 0 & $1 \mathrm{C}$ \\
\hline Leaf juice in Van Tieghem cells... & 6 & 0 & 0 & $6 \mathrm{C}$ \\
\hline \multicolumn{5}{|l|}{ Stigmina: } \\
\hline Living leaves (September, 1938):.. & 11 & 0 & 0 & $6 \mathrm{C}$ and $5 \mathrm{~S}$ \\
\hline Czapek's agar. . . . . . . . . . & $16 \dagger$ & 10 & 0 & $6 \mathrm{C}$ \\
\hline Leaf juice in Van Tieghem cells... & 6 & 0 & 0 & $6 \mathrm{C}$ \\
\hline \multicolumn{5}{|l|}{ Ascospore: } \\
\hline Living leaves (May, 1938). & 15 & 10 & 0 & $5 \mathrm{C}$ \\
\hline Czapek's agar............. & $74 \ddagger$ & 72 & 0 & 0 \\
\hline Leaf juice on slides....... & $8 \ddagger$ & 1 & 0 & $5 \mathrm{C}$ \\
\hline Leaf juice in Van Tieghem cells... & $4 \ddagger$ & 2 & 0 & 0 \\
\hline
\end{tabular}

* The letters "C" and "S" indicate the type of spore (Cercospora or Stigmina, respectively) predominating.

$\dagger$ Isolates selected at random.

† Some of these inoculations failed to produce spores.

grouped into no less than fourteen different types. While occasional differences were noted in the size of spores produced by the different isolates, these variations could not be correlated with the kind of spore from which the culture originated.

Spermatia (fig. 2, $G$ and $N$ ) of each of the three organisms developed both in cultures and on infected leaves. In cultures of Mycosphaerella polymorpha, dense mycelial masses developed containing these small bacilluslike bodies. But when these were streaked on nutrient media, no evidence of spermatial germination was obtained.

Of the 50 single-spore cultures of Stigmella Platani-racemosae made in these tests, 1 isolate produced a flat, spreading colony, when grown on 


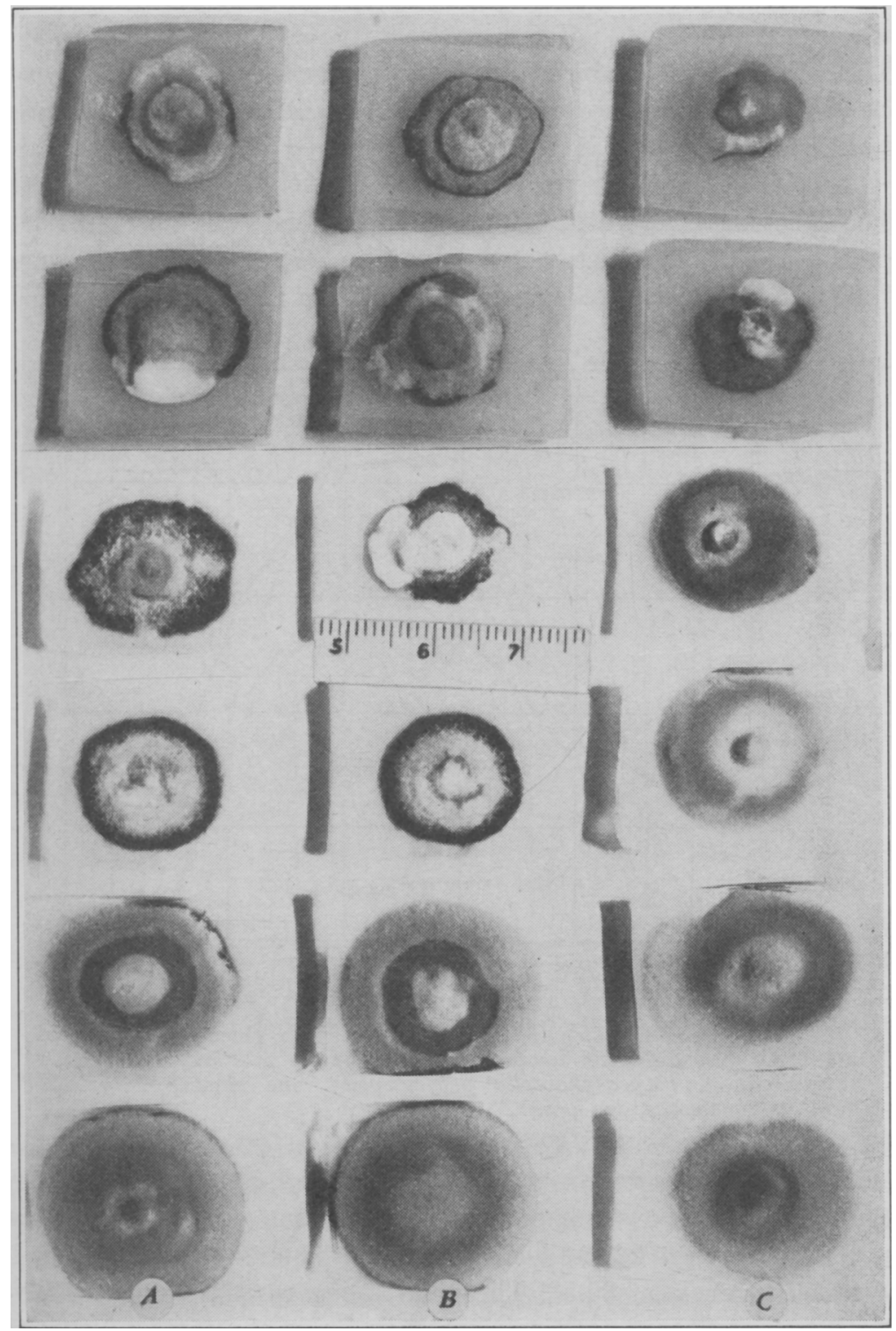

Fig. 7.-Colonies grown on Czapek's agar from single-spore culture isolations (different spore types) of Mycosphaerella polymorpha. The vertical rows show colony variation: $A$, colonies from Cercospora-type spores; $B$, from Stigmina-type spores; $C$, from ascospores. The horizontal rows show colonies of similar types of growth. 
glucose potato agar at room temperature; the other 49 produced colonies that were elevated.

The colonies of Stigmina Platani closely resembled those of Stigmella Platani-racenosac but were less variable than those of Mycosphaerella polymorpha.

\section{TEMPERATURE RELATIONS}

The effects of temperature on these three species of fungi were determined by the use of constant-temperature chambers having a range of $10^{\circ}-35.5^{\circ} \mathrm{C}$. $\Lambda$ few tests were also made in a refrigerator at $5^{\circ}$. The

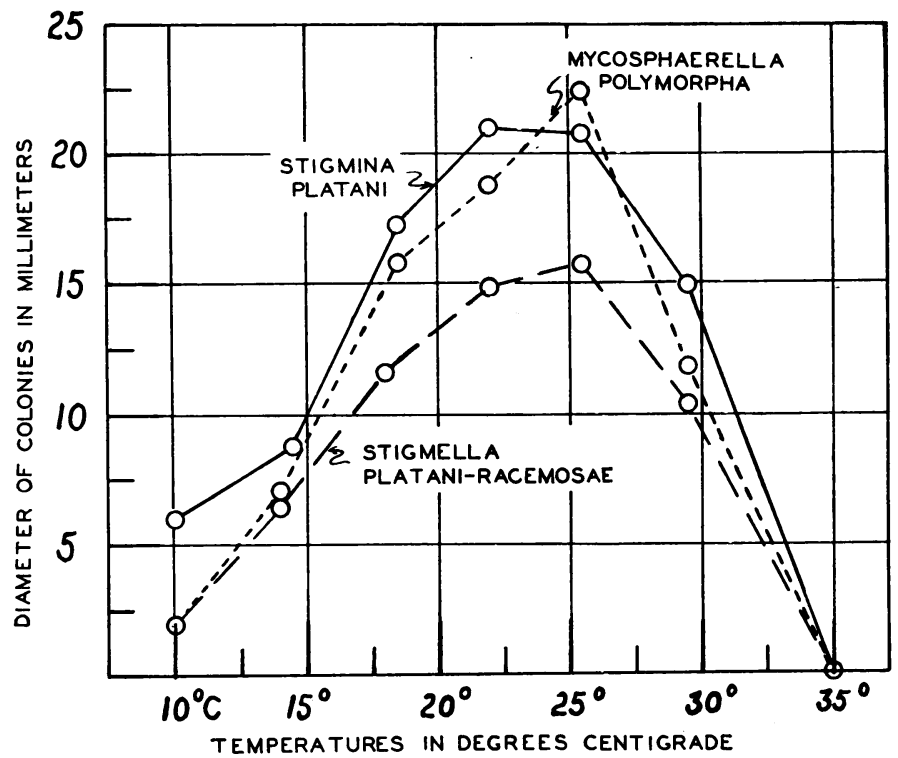

Fig. 8.-Growth response of colonies grown on glucose potato agar $\left(\mathrm{pH}^{4.7}\right)$ at different temperatures: Stigmina Platani, six weeks; Stigmina sp. (Mycosphaerella polymorpha), one month; Stigmella Platani-racemosae, one month.

diameter of colonies grown on glucose potato agar was used as an indicator of mycelial growth response. The optimum for all three organisms (fig. 8) was between $22^{\circ}$ and $26^{\circ}$. They showed slight growth below $10^{\circ}$, but failed to grow at $35.5^{\circ}$. The growth curves of Stigmella Plataniracemosae and Stigmina Platani are flatter near the optimum than that of Mycosphaerella polymorpha. Stigmella Platani-racemosae gave the best sporulation between $14^{\circ}$ and $19^{\circ}$; the other two fungi did not sporulate within this range during the time of the experiment.

The temperature at which the maximum germination of conidia of Stigmella Platani-racemosae and of Mycosphaerella polymorpha (fig. 
9) took place (conidia of Stigmina Platani were not tested) agrees with that of the optimum temperature for growth of the mycelia of these two fungi. At $25^{\circ} \mathrm{C}$, there was 75 per cent germination within $281 / 2$ hours, and 90 per cent within 47 hours. The count was based upon 50 spores selected at random. The germ tubes varied in length with the temperature; at $25^{\circ}$ they reached an average length of $15.5 \mu$ in 47 hours.

The thermal death points of the mycelia and spores of the three fungi were tested with cultures and conidia taken directly from the leaves of their respective hosts. Mycelium obtained from nonsporulating colonies

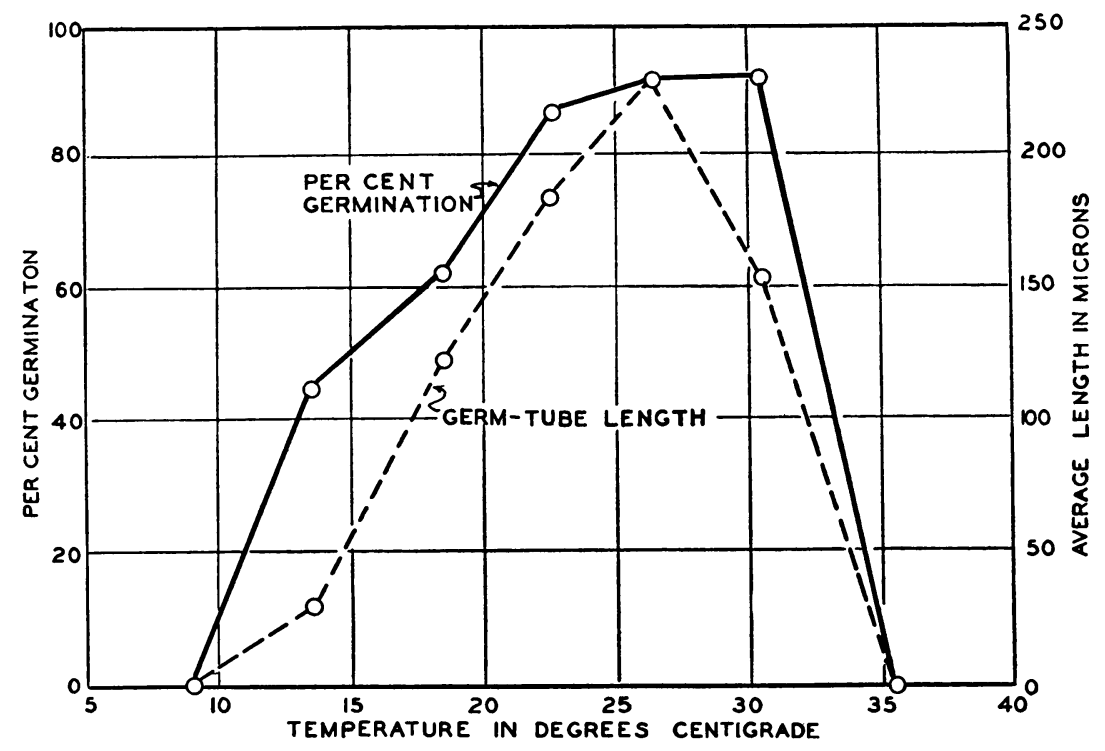

Fig. 9.-Spore germination and germ-tube growth of Stigmina sp. (Mycosphaerella polymorpha) on glucose-potato-agar film on slides for 48 hours at different temperatures.

was broken into bits by means of a sterile rod. Concentrations of the suspensions of mycelia or conidia were adjusted by the addition of sterile water. These suspensions were put into sterile capillary tubes, 4 to 5 inches long, after which the tubes were sealed by means of a microburner. The temperature of the bath, which consisted of a large pan of water, was modified by means of a microburner. After exposure for a 10-minute period in the bath, the capillary tubes were surface-sterilized in mercury bichloride and washed in sterile water; the contents were then ejected upon glucose-potato-agar plates. Observations of the resultant growth were made at intervals of from one day to two weeks. The results of these tests are shown in table 4 . 
The thermal death point of mycelia and spores of both Stigmella Platani-racemosae from Platanus racemosa and Stigmina Platani from $P$. orientalis was found to lie between $45^{\circ}$ and $46.5^{\circ} \mathrm{C}$. The mycelium and spores of the Stigmina stage of Mycosphaerella polymorpha had a thermal death point between $47^{\circ}$ and $48^{\circ}$, approximately $2^{\circ}$ higher than that of the other two fungi.

Mycosphaerclla was cultured in sterile leaf juice in Van Tieghem cells to test the influence of temperature on sporulation. Five cultures were

TABLE 4

Determination of Thermal Death Poin't of Mycelium and SPORES OF THE THREe Fungi

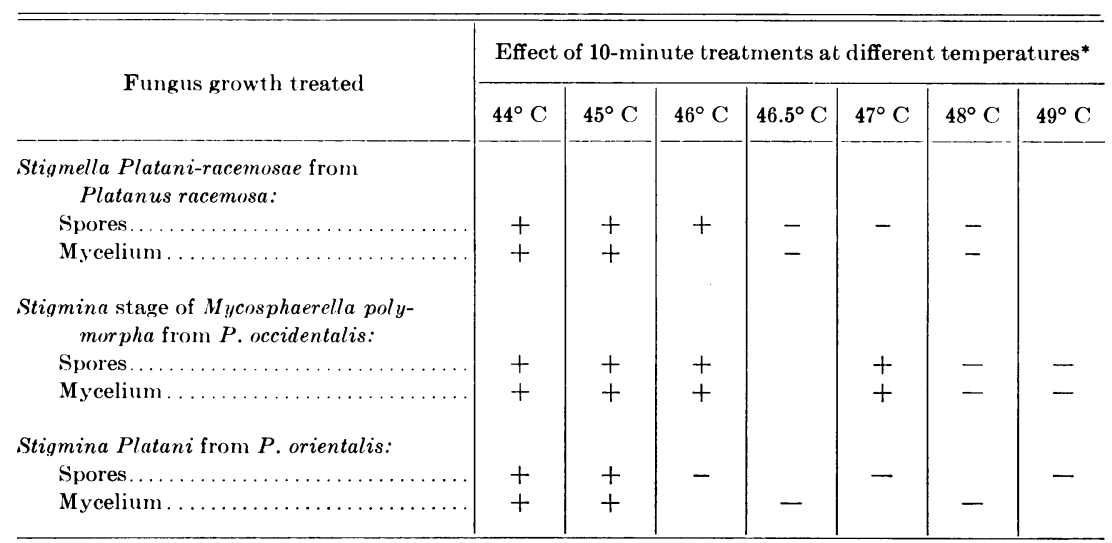

* In the columns $+=$ continued fungus growth indicated; $-=$ no growth and probable death of the organism; blank spaces indicate that results at these temperatures were not recorded. For description of treatments see text (p. 223).

maintained at $15^{\circ} \mathrm{C}, 5$ at $19^{\circ}, 16$ at room temperature $\left(21^{\circ}-33^{\circ}\right), 5$ at $26.5^{\circ}$, and 5 at $30.5^{\circ}$. Of the 16 cultures grown at room temperature, 6 originating from Stigmina spores produced a mixture of Stigmina- and Cercospora-type conidia ; 6 originating from Cercospora-type spores also produced conidia of both kinds; 2 of the remaining 4 cultures, which originated from ascospores, produced Cercospora-type conidia only, and 2 remained sterile. Sporulation did not occur in any of the other cultures with the exception of one of those maintained at a temperature of $26.5^{\circ}$, which produced Cercospora-type conidia two weeks after inoculation.

Cercospora-type conidia were often found in cultures from the conidia (both Cercospora- and Stigmina-type) and ascospores of Mycosphaerella polymorpha, but were never found in cultures of Stigmella Platani-racemosae or of Stigmina Platani.

Results of inoculations with cultures from single spores on leaves of Platanus racemosa would seem to indicate that temperature may be a factor in determining the type of spore that will develop on the infected 
leaf tissue (table 5). The production of the Cercospora-type was favored by the higher temperatures, and the Stigmina-type developed best at the lower temperatures.

\section{HYDROGEN-ION RELATIONS}

The hydrogen-ion relations of Stigmella Platani-racemosae and of Stigmina Platani were tested in carrot dextrose broth (fig. 10), on Czapek's agar, and on carrot dextrose agar. Mycosphaerella polymorpha

\section{TABLE 5}

Sporula'tion From Single-SPORE Inoculations on Leaves of Platanus racemosa With Spores of Mycosphaerella polymorpha under Different TemperaTURe Conditions ; NOVEMber--Decem ber, 1938

\begin{tabular}{|c|c|c|c|c|c|c|}
\hline \multirow{2}{*}{$\begin{array}{l}\text { Type of spore } \\
\text { isolated and } \\
\text { culture no. }\end{array}$} & \multicolumn{2}{|c|}{$\begin{array}{l}\text { Lathhouse, temperature } \\
\text { variable* }\end{array}$} & \multicolumn{2}{|c|}{$\begin{array}{l}\text { Cool greenhouse, } \\
\text { temperature } 21^{\circ}-27^{\circ} \mathrm{C}\end{array}$} & \multicolumn{2}{|c|}{$\begin{array}{l}\text { Warm greenhouse, } \\
\text { temperature } 27^{\circ}-32^{\circ} \mathrm{C}\end{array}$} \\
\hline & $\begin{array}{l}\text { Inocu- } \\
\text { lations }\end{array}$ & Sporulation $\dagger$ & $\begin{array}{l}\text { Inocu- } \\
\text { lations }\end{array}$ & Sporulation $\dagger$ & $\begin{array}{l}\text { Inocu- } \\
\text { lations }\end{array}$ & Sporulation $\dagger$ \\
\hline & number & & number & & number & \\
\hline \multicolumn{7}{|l|}{ Ascospore: } \\
\hline No. $5 \ldots$ & 1 & S only & 1 & None & 1 & None \\
\hline No. $11 \ldots$ & 1 & $\mathrm{~S}$ and $\mathrm{C}$ equal & 1 & None & 1 & None \\
\hline No. $17 \ldots$ & 1 & S only & 1 & None & 1 & None \\
\hline No. $22 \ldots$ & 2 & S only & 2 & None & 2 & C only \\
\hline No. $23 \ldots$ & 2 & None & 2 & None & 2 & C only \\
\hline No. $34 \ldots$ & 2 & $\begin{array}{l}\text { Mixed, S pre- } \\
\text { dominant }\end{array}$ & 1 & $\mathrm{~S}$ and $\mathrm{C}$ equal & 1 & C only \\
\hline \multicolumn{7}{|l|}{ Stigmina-type: } \\
\hline No. $227 \ldots \ldots$ & 1 & S only & 1 & None & 1 & None \\
\hline No. $239 \ldots \ldots \ldots$ & 1 & None & 1 & None & 1 & $\begin{array}{c}\text { Mixed, C pre- } \\
\text { dominant }\end{array}$ \\
\hline \multicolumn{7}{|l|}{ Cercospora-ty pe } \\
\hline No.115ł........ & 1 & None & 1 & $\begin{array}{c}\text { Mixed, C pre- } \\
\text { dominant }\end{array}$ & 1 & None \\
\hline No. $118 \ldots \ldots$ & 1 & None & 1 & None & 1 & None \\
\hline No. $130 \ldots \ldots$. & 1 & None & 1 & None & 1 & $\begin{array}{c}\text { Mixed, C pre- } \\
\text { dominant }\end{array}$ \\
\hline No. $136 \ldots \ldots \ldots$ & 1 & None & 1 & $\begin{array}{l}\text { Mixed, C pre- } \\
\text { dominant }\end{array}$ & 1 & None \\
\hline
\end{tabular}

* No temperature records were taken for the lathhouse, but outside temperatures as recorded at the Citrus Experiment Station for November were: minimum, $2^{\circ} \mathrm{C} ;$ maximum, $29^{\circ} ;$ mean minimum, $4.3^{\circ}$; mean maximum, $24.6^{\circ}$. For December the minimum was $2^{\circ}$; maximum, $32^{\circ}$; mean minimum, $6.5^{\circ}$; mean maximum, $21.9^{\circ}$.

$\dagger$ The letters "S" and "C" indicate the type of sporulation, Stigmina or Cercospora, respectively.

‡ Organism isolated from inoculation by a previous single-spore culture.

was not tested. The fungi were grown in the liquid medium for three and one-half months and on the solid media for six weeks, at their optimum temperature of $25^{\circ} \mathrm{C}$. In the cultures on Czapek's agar and on carrot dextrose agar, the minimum $\mathrm{pH}$ value was 2.0 , the optimum 5.0 , and the maximum between 7.0 and 8.0. Growth was slight at the alkaline end of the range. Growth of the fungi caused increased alkalinity in liquid cul- 
tures, whereas the control liquids were more acid at the end than at the beginning of the experiment (fig. 10). There was little change in the $\mathrm{pH}$ value of the media where the initial concentration was $\mathrm{pH}$ 7.0.

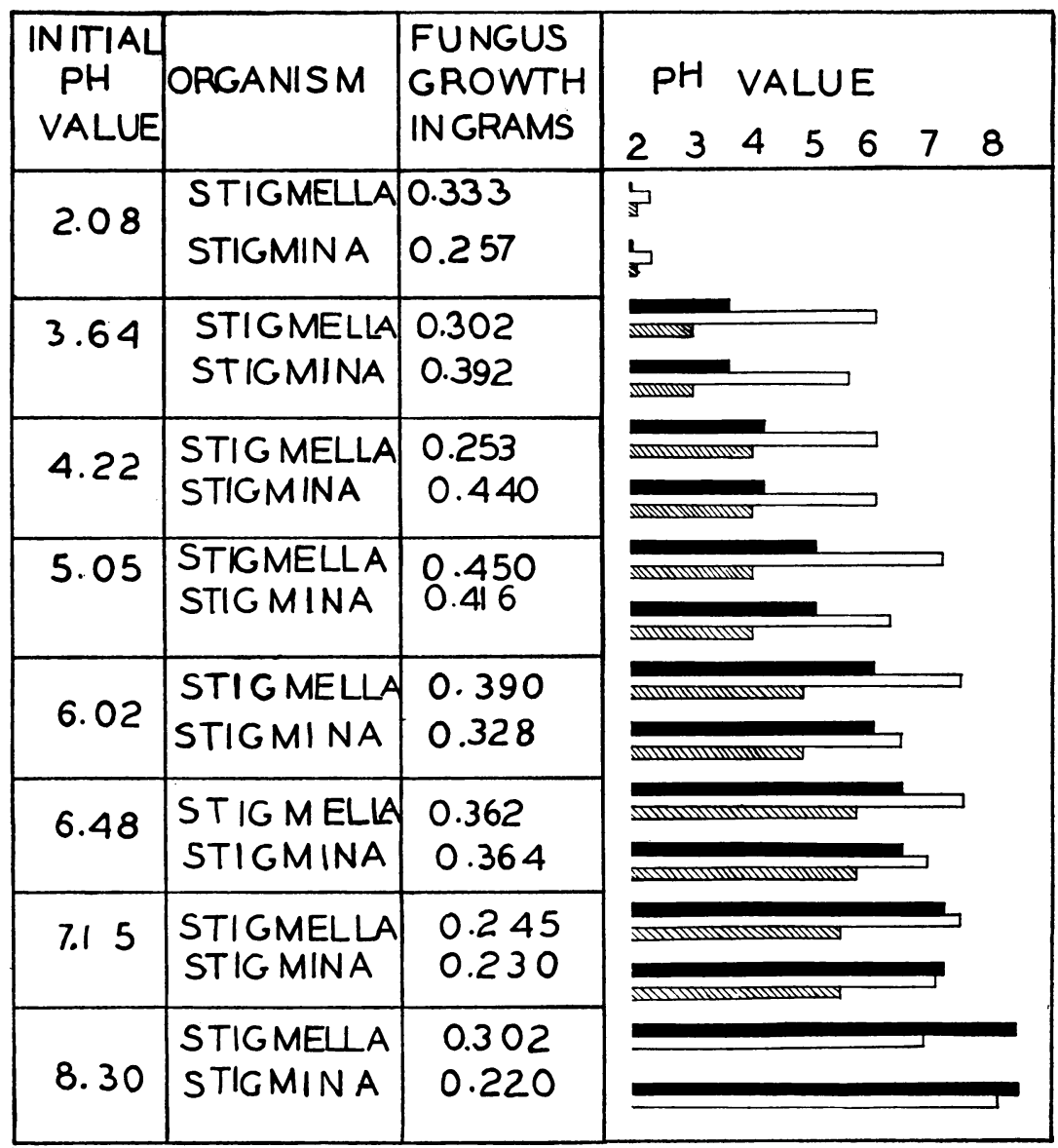

INITIAL PH

FINAL PH OF CONTROL

¿ FINAL PH WITH ORGANISM

Fig. 10.-Hydrogen-ion relations of Stigmella Platani-racemosae and of Stigmina Platani grown for three and one-half months on the surface of 100 ce of carrot dextrose broth in 200-ce flasks at $25^{\circ} \mathrm{C}$. Control liquids contained no fungus inoculation.

Germination of spores and germ-tube length of Stigmella Plataniracemosae at different $\mathrm{pH}$ values, when tested in carrot-dextrose-agar drops on slides for 28 hours, showed maximum germination of approximately 85 per cent at $\mathrm{pH} 5.0$. The germ-tube length, however, was great- 
est at $\mathrm{pH} 4.5$. At $\mathrm{pH} 5.0$, the average germ-tube length was decreased by about one half of that at $\mathrm{pH} 4.5$. The juice of leaf blades of Platanus raccmosa had a $\mathrm{pH}$ value of 4.8 in $\Lambda$ pril, as determined by the quinhydrone glass electrode; that of $P$. acerifolia gave a reading of $\mathrm{pH} 5.1$ in September; there is, therefore, a close correlation between the $\mathrm{pH}$ of the leaf juice and that which is optimum for the pathogen.

\section{CONTROL}

The writers have conducted no experiments for control of the leaf spot on Platanus racemosa. The other two leaf spots are not found in California. Should control be found necessary, treatment with bordeaux mixture, as suggested by Felt and Rankin (6) in the control of Gnomonia veneta (Sacc. and Speg.) Kleb., which causes leaf and twig blight of plane tree, or sycamore, should be satisfactory. These writers recommend that the trees be sprayed with bordeaux mixture after the buds burst and before the leaves are half grown, and that a second application be given one week later. A third and fourth spraying at intervals of two weeks are suggested if the season is rainy. It is anticipated that burning the fallen leaves would lessen the severity of the initial infections and might well be a very important control measure.

\section{DISCUSSION AND SUMMARY}

On the basis of morphological and physiological differences and of host specificity, it is shown that three distinct species of fungi are involved in leaf spots on Platanus (plane tree). Each produces a different symptom complex and has a distinct geographical host range.

Stigmina Platani (Fckl.) Sacc. on Platanus orientalis L., from Europe, failed to infect other species of Platanus.

Stigmella Platani-racemosae Dearn. and Barth. is pathogenic to Platanus racemosa Nutt. in California. In pathogenicity tests it proved to be capable of infecting $P$. Wrightii S. Wats., not previously known to be susceptible. Other species of Platanus proved to be immune.

The fungus called, in this paper, Mycosphaerella polymorpha and found on Platanus occidentalis L., occurs in the southeastern and southern central United States. It was found to be pathogenic also on P. racemosa, $P$. Wrightii, and $P$. acerifolia, but not on $P$. orientalis. This organism produces polymorphic conidia that range in shape from those typical of Stigmina on the one hand, to those typical of Cercospora on the other. Conidia of each type and also of intermediate types may be borne on the same conidiophoral fascicle. This conidial stage has hitherto not been named, for the reason that it has been erroneously identified as Stigmina Platani. 
The proper denomination of these three fungi could only be accomplished if their perfect stages could be developed under artificial conditions or were found to exist in the natural state on decaying leaves. The writers attempted unsuccessfully to induce the development of the perithecial stage of Stigmella Platani-racemosae under California conditions. Furthermore, at the request of the writers, leaves infected with Stigmina Platani were maintained in Cyprus under natural conditions, to permit the development of the perfect stage, but to no avail. Each of these organisms probably possesses a perithecial stage. Evidence for this is found in the fact that each possesses a spermatial stage, as previously noted (see "Culture Studies," p. 220). In the light of our knowledge of other ascomycetes, the production of spermatia may properly be interpreted as indicative of the presence of perithecia in the developmental cycle. The fact that these organisms can survive from year to year as conidial stages shows that the perfect stage is not essential to survival; but this is not proof of the nonexistence of a perfect stage.

The perithecial stages of Mycosphaerella polymorpha and M. platanifolia indicate that these species may be identical. The measurements for freshly discharged, hence mature, ascospores of M. Stigmina-Platani (M. polymorpha), given by Wolf $(24$, p. 58$)$, are 17-19 $\times 6-7 \mu$; and for those of $M$. platanifolia, $8-10 \times 4-4.5 \mu$. In the present study, the range of measurements of ascospores discharged from perithecia borne in leaves of Platanus occidentalis was 8-19 $\times 4-7 \mu$, as previously stated (p. 215), and included spores 12.0, 13.5, 14.5, and $16 \mu$ long and 4.8, 5.4, and $5.6 \mu$ wide. These measurements indicate that there are spores intermediate in size between those published by Wolf for the two species of Mycosphaerella.

Wolf (24, p. 59) mentions two types of colonies : one type isolated from either the conidia or the ascospores of Mycosphaerella Stigmina-Platani (M. polymorpha) and the other type from either the conidia of Cercospora platanicola or the ascospores of $M$. platanifolia. But he states further ${ }^{8}$ that the two types of colonies found in the present studies (see "Culture Studies," p. 219) and shown in figure 7 (p. 221) appear to have the same characteristics as those found in his studies.

Differences in appearance of colonies within one and the same species, however, are now known to be characteristic of an increasingly large number of fungi. The evidence in hand at present, therefore, as to the possible identity of Mycosphaerella polymorpha and M. platanifolia must be regarded as insufficient, and the solution of the problem must be left for future study.

${ }^{8}$ Wolf, F. A. In letter to the junior author dated August 10, 1940. 
Unfortunately, Wolf (24) used the specific name Stigmina-Platani for the Mycosphaerella on Platanus occidentalis, whereas the present studies establish the fact that the conidial fungus Stigmina Platani is specifically distinct and occurs only on $P$. orientalis. This error, if preserved, would add to the nomenclatorial confusion, especially if the perithecial stage of Stigmina Platani, when discovered, should happen to be found to belong to Mycosphaerella, as this genus is now delimited. It has been deemed advisable, therefore, to reject the name Mycosphaerella Stigmina-Platani Wolf, and the new name Mycosphaerella polymorpha is proposed in its place.

Stigmina Visianica Sacc. appears to be identical with the conidial stage of Mycosphaerella polymorpha.

Each species has been isolated and grown in single-spore culture. Sporulation in culture was best induced by growth on Platanus leaf juice sterilized by filtration and on Czapek's agar.

Temperatures within the range of $22^{\circ}$ to $26^{\circ} \mathrm{C}$ were found to be optimal for growth of each of the three species.

Germination of spores and mycelial growth occurred best in media having an acidity of approximately $\mathrm{pH}$ 5.0.

Removal of fallen leaves and spraying of the trees may be anticipated to be effective control measures.

\section{ACKNOWLEDGMENTS}

The writers wish to express appreciation to Professor William T. Horne, under whose supervision the work was conducted, and to others, whose generous coöperation made these studies possible (see "Materials Used," p. 208). Grateful acknowledgment is made to Dr. H. S. Fawcett for assistance in preparation of the manuscript. Valuable information, criticisms, and suggestions were also given by Dr. F. A. Wolf, Dr. L. J. Klotz, Dr. D. E. Bliss, and Dr. C. L. Shear. Dr. Wolf was especially helpful in the problem of nomenclature. The photomicrographs were taken by Dr. L. J. Klotz. 


\section{LITERATURE CITED}

1. Apostolides, C. A.

1929. A leaf spot of sycamore caused by Stigmina platani (Fuckel) Sacc. Phytopathology 19:667-71.

2. BUbÁk, Fr.

1914. Ein Beitrag zur Pilzflora von Tirol und Istrien. Ann. Mycol.12(2) :205-20.

3. COOKE, M. C.

1883. On Sphaerella and its allies. Jour. Bot. $21: 67-71,106-20,136-39$.

4. DeARness, JoHn.

1929. New and noteworthy fungi. VI. Hyphomycetes. Mycologia 21(6):326-32.

5. ElLis, J. B., and B. M. Everhart.

1887. Additions to Cercospora, Gloeosporium, and Cylindrosporium. Jour. Mycol. 3(2) :13-22.

6. FELt, E. P., and W. Howard Rankin.

1932. Insects and diseases of ornamental trees and shrubs. $507 \mathrm{p}$. The Macmillan Company, New York, N. Y.

7. HARKNESS, W. H.

1885. Fungi of the Pacific Coast. California Acad. Sci. Bul. 1(3):159-76. (See specifically p. 164.)

8. HoFFer, G. N.

1914. The more important fungi attacking forest trees in Indiana. Indiana State Bd. Forestry Ann. Rept. 14:84-97.

9. International Botanical Congress.

1935. International rules of botanical nomenclature. Adopted by the International Botanical Congresses of Vienna, 1905, Brussels, 1910, and Cambridge, 1930. 3d ed. 151 p. Gustav Fischer, Jena.

10. Jennings, H. S.

1890. Some parasitic fungi of Texas. Texas Agr. Exp. Sta. Bul. 9:23-29. (See specifically p. 28.)

11. Martin, G. Hamilton.

1925. Diseases of forest and shade trees, ornamental and miscellaneous plants in the United States in 1923. Plant Disease Reporter Sup. [Issued by the U. S. Dept. Agr. Bur. Plant Indus.] 37:349-446. (Mimeo.)

12. McClatchie, A. J.

1897. Seedless plants of southern California. South. California Acad. Sei. Proc. 1:337-98.

13. NATTRASS, R. M.

1933. Annual Report of the Mycologist for the year 1932. [Cyprus.] Dept. Agr. Ann. Rept. 1932:44-49.

14. Patterson, Flora W.

1902. A collection of economic and other fungi prepared for distribution. U. S. Dept. Agr. Bur. Plant Indus. Bul. 8:7-31.

15. PIPAL, F. J.

1916. A list of plant diseases of economic importance in Indiana, with bibliography. Indiana Acad. Sci. Proc. 1915:379-413. (See specifically p. 394.)

16. Rawlins, T. E.

1933. Phytopathological and botanical research methods. $156 \mathrm{p}$. John Wiley and Sons, Inc., New York, N. Y. 


\section{RIDGWAY, $R$.}

1912. Color standards and color nomenclature. 43 p. 53 color plates. Published by the author, Washington, D. C.

18. SACCARDo, P. A.

1878. Fungi Veneti novi v. critici. Seriei VIII, Appendicula. In: Michelia: commentarium Mycologicum 1:351-55. Typis Seminarii, Patavii.

19. SACCARDO, P. A.

1880. Conspectus generum fungorum Italiae inferiorum, nempe ad Sphaeropsideas, Melanconieas, et Hyphomyceteas pertinentium systemate sporologico dispositorum. In: Michelia: commentarium Mycologicum 2:1-38. Typis Seminarii, Patavii.

20. SACCARDO, P. A.

1886. Sylloge Fungorum IV. Parta VII. (Sylloge Hyphomycetum) p. 394.

21. Smith, Donald J., and C. O. Smith.

1939. The use of special media for sporulation of fungi. Phytopathology 29:821.

22. THÜMEN, F.

1871. Mycologische Notizen von Griechenland. Bot. Ztg. 29:27.

23. Tracy, S. M., and F. S. Earle.

1895. Mississippi fungi. Mississippi Agr. Exp. Sta. Bul. 34:80-122.

24. WOLF, F. A.

1938. Life histories of two leaf-inhabiting fungi on sycamore. Mycologia $30(1): 54-63$.

25. WoLF, F. A.

1938. Correction. (Cercospora platanifolia Ellis and Ev. to C. platanicola Ellis and Ev.) Mycologia 30(2):243. 